DOI: https://doi.org/10.32838/2523-4803/70-4-9

УДК $658.001 .76+330.341 .1$

Лісовська Л.С.

кандидат економічних наук, доцент,

Національний університет «Львівська політехніка»

\title{
Lisovska Lidiya
}

Lviv Polytechnic National University

\section{ВИДИ ТА ФОРМИ ПРОЯВУ ВЗАЕМОДІЙ У ІННОВАЦЙНИХ ПРОЦЕСАХ}

У статті досліджено проблему термінологічного обтрунтування сис-теми взаємодії у інноваџійних прочесах через визначення категорій "система», "зв'язки», "взаємодія», "економічна взаємодія», «взаємодія у інновачійних проиесах». Доведено, що взаємодія як наукова категгорія є предметом досліджень різних галузей. Диференціація розуміння взаємодї пов'язана зі специфікою відносин, процесів та явищ, які вона описує, та складом ї̈ учасників. Автор сформувала групування видів взаємодій за певними ознаками, що дає змогу визначити місце та значення економічних взаємодій у начіональній економіці. Виокремлено особливу роль споріднених форм взаємодій, які розташовані на перетині кількох ознак. За результатами поведених досліджень автор надає власне трактування поняття «взаємодія у інновачійних прочесах» та актуалізує їі сучасні форми прояву у відкритих моделях інновачійного прочесу.

Ключові слова: взаємодія, інновачійний прочес, системи взаємодї, економічна взаємодія, взаємодія у інноваційних прочесах.

Постановка проблеми. Для реалізації завдань інноваційного розвитку та здійснення етапів інноваційного процесу формується система взаємодій. Багато науковців та практиків у своїй діяльності доходять висновку, що поняття інновацій все частіше пов'язують не тільки 3 науково-технічною діяльністю чи з етапами освоєння виробництва, а й із процесом налагодження різних форм та методів взаємодії між працівниками, організаціями та навколишнім середовищем бізнес-діяльності. Показники ефективності формування систем взаємодії визначають рівень показників ефективності інноваційної активності регіону, країни.

Аналіз останніх досліджень і публікацій. Дослідження сутності поняття «взаємодія» можна зустріти у різних галузях науки, оскільки вона визнається явищем, яке виникає у різних системах, між різними об'єктами та суб'єктами, має складну побудову, власні принципи формування, які можуть набувати різних значень у різних середовищах .

Взаємодією називають і як статичний стан, і як динамічний взаємний зв'язок між предметами, погоджені дії між об'єктами та суб'єктами. Взаємодіяти значить «перебуваючи у зв'язку, взаємно проявляти дію, або погоджено взаємно діяти, бути у взаємодії» [1, с. 125]. О.О. Кваша (2012) стверджує, що у будьякій системі взаємодія виступає як таке відношення, в якому причина і наслідок постійно міняються місцями. Точний вияв факторів, які становлять причину у формі взаємодії зовнішнього 3 внутрішнім, дає можливість виокремити причинний зв'язок таким чином, що виявляється трансформація причини і наслідку [2, с. 36].
К.Ю. Тушко (2017) виокремлює визначення широкого та вузького змістів поняття «взаємодія». Широким розумінням поняття «взаємодії» $є$ розуміння його як особливого типу зв'язку, що передбачає взаємні впливи на сторони та спровоковані ними зміни. Вузьким змістом поняття «взаємодія» $є$ обмін інформацією, іншими словами - спілкування. Таку взаємодію назвали суб'єкт-суб'єктною [3, с. 207].

А.В. Ортина (2019) досліджує взаємодією економічних суб'єктів у реальному секторі економіки, під якою розуміє узгоджені дії економічних суб'єктів 3 досягнення цілей сталого розвитку, а також взаємний вплив їхніх дій на досягнення своїх цілей, задоволення інтересів [4, с. 140]. В.М. Геєць (2015) називає взаємодію ринку та держави механізмом, який забезпечує узгоджене існування всього різноманіття людської діяльності та її продуктів [5, с. 2].

У досліджених наукових працях виділено велику кількість видів взаємодій, які розглядаються у різних площинах відносин суспільного життя. Визнаючи пріоритет явища взаємодії у процесах економічного та інноваційного розвитку, бачимо, що залишаються малодослідженими питання визначення місця і значення видів взаємодії у системі суспільних відносин.

Формулювання цілей статті. Метою статті $\epsilon$ вивчення поняття взаємодії у різних галузях науки та пізнання навколишнього світу, побудова класифікації видів взаємодій, обгрунтування поняття взаємодії у інноваційних процесах та визначення його місця у розробленій класифікації. 
Виклад основного матеріалу. Понятійну основу методологічного базису системи взаємодії у інноваційних процесах утворюють категорії «система», «зв’язки», «взаємодія», «економічна взаємодія», «взаємодія у інноваційних процесах».

В енциклопедичних виданнях системою називають «сукупність яких-небудь елементів, одиниць, частин, об'єднаних за спільною ознакою, призначенням; будова, структура, що становить єдність закономірно розташованих та функціонуючих частин; сукупність способів, методів, прийомів здійснення чого-небудь» [1, c. 1321].

Можна виділити два концептуальні підходи до розуміння «системи»: сукупність елементів (об'єктів); структура, яка визначається кількістю та видом зв'язків між елементами.

У теорії інноватики системи використовують для позначення як статичних об'єктів та явищ, так i для позначення динамічних процесів зміни явищ та об'єктів: сукупності різних інструментів та важелів управлінського впливу на об'єкти інноваційного процесу, форми організування інноваційного процесу, порядку взаємовідносин між елементами механізму реалізації інноваційного процесу загалом.

Зв'язки як елементи «системи» існують, якщо вони впливають на пове-дінку елементів. Зв'язки бувають різноманітних видів, зокрема на рис. 1 наведено їх групування за суттєвими ознаками.

Взаємодії властива стану динамічних змін, взаємної активності об'єктів, тоді як взаємозв'язок може мати місце між об'єктами, що знаходяться в стані спокою, рівноваги, стабільності. Системний підхід потрібно застосувати і до розгляду поняття взаємодії.

Причому взаємодія може відбуватися і 3 незнайомими суб'єктами. У процесі здійснення взаємодії суб'єкти можуть здійснювати вплив один на іншого та відповідно взаємно змінювати соціально-психологічні стани, цінності, інтереси, наміри, цілі діяльності.

Взаємодія у суспільстві існує у різних проявах та різних сферах суспільного життя. Диференціація розуміння взаємодії пов'язана з специфікою відносин, процесів та явищ, які вона описує, та складом їі учасників. Види взаємодій можна поділити за певними ознаками (рис. 2). Ця класифікація в основі має дихотомічний поділ видів взаємодій та дозволить визначити місце та особливості взаємодії у інноваційних процесах.

Взаємодія може бути здійснена у таких взаємопротилежних проявах, як (рис. 2): співробітництво, що передбачає такі дії, які сприяють суб'єкту або групі суб'єктів у спільній діяльності; суперництво, що включає дії, які перешкоджають спільній діяльності та порозумінню.

За кількісним аспектом, тобто кількістю суб'єктів, які беруть участь у взаємодії, розрізняють взаємодію між групами, між особистістю та групою, між двома особистостями.

За моделлю реалізування взаємодії виділяють такі взаємодії: спільно-індивідуальна (учасник виконує свою частину спільної роботи незалежно); спільнопослідовна (спільну роботу послідовно виконують всі учасники); спільно-взаємопов'язана (одночасна взаємодія між усіма учасниками).

Взаємодія може здійснюватися 3 різною періодичністю в часі: один раз (одноразова), багато разів, тобто більше одного разу (багаторазова), або час від часу у зв'язку із виникненням певних чинників (періодична).

Вивчають явища навколишнього світу в живій та неживій природі, що є елементами систем взаємодій у таких природничих науках як: фізико-технічні і математичні (математика, інформатика, механіка, фізика i астрономія); хімічні і біологічні науки (хімія, біологія, екологія); науки про землю (геологія, географія, геофізика); аграрні науки (грунтознавство, рослинництво, зоотехнія, ветеринарна медицина); медичні науки (медицина).

У системі взаємодій особливе місце надається процесам взаємодії суб'єктів з природою. О. Молчанюк (2019) виділяє систему взаємодій «людина-природа», яку варто розглядати з позиції суб' єктивації природи й налагодження міжсуб'єктних відносин, а суть взаємодії людини $з$ природою потрібно розглядати через синергетичний підхід [8, с. 101]. Автор виділяе три основні типи взаємодії: узгоджена; неузгоджена; стихійна.

В.М. Сурженко, А.А. Бессараб (2019) розглядають процес взаємодії людини та природи як складний діалектичний конфліктний процес, в якому системи доповнюють один одного і існують одна з одною [9, с. 3].

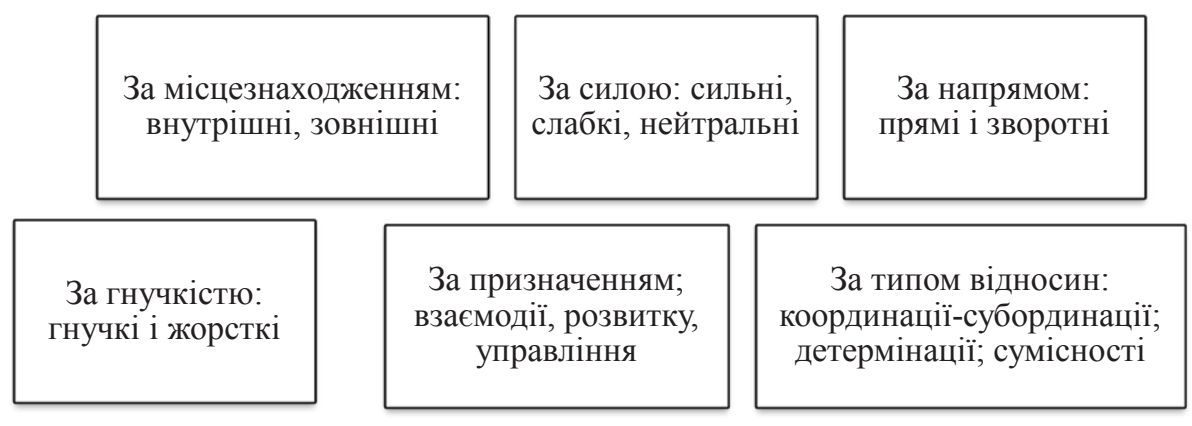

Рис. 1. Види зв'язків у системах

Джерело: складено на основі [6, с. 11] 


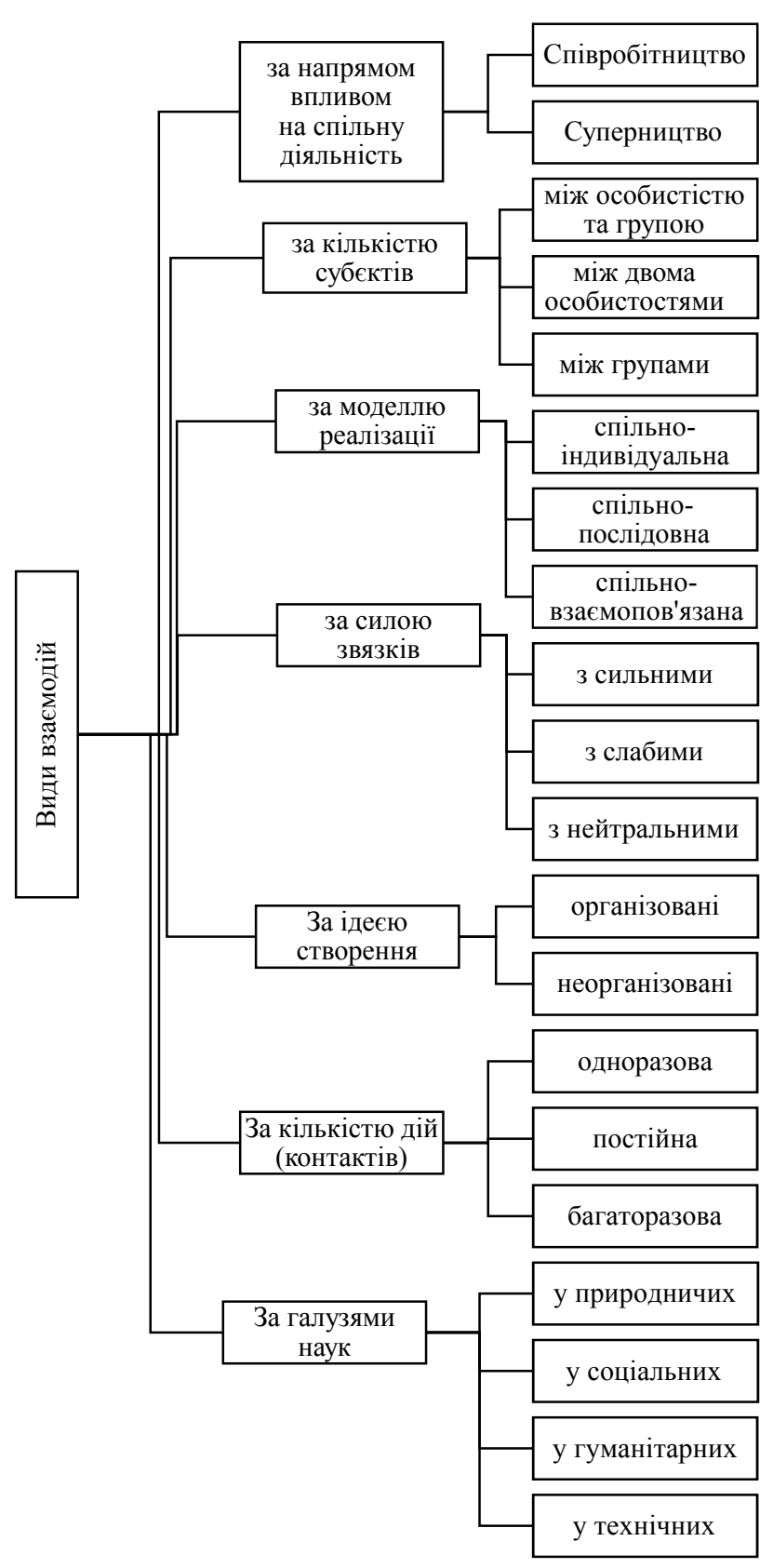

Рис. 2. Види взаємодій

Джерело: складено на підставі [7, с. 44]

Фундаментальні взаємодії у фізико-технічних i математичних науках розглядаються як взаємодії між елементарними частинками та тілами і поділяються на гравітаційні, електромагнітні, сильні та слабкі. У процесі механічних взаємодій обмін енергією відбувається не тільки на фоні дії гравітаційних сил, але і за участі пов'язаних із ними сил взаємодії матеріальних мас біологічних та оточуючих їх багаточисельних об'єктів середовища [10, с. 29].

Категорія взаємодії має методологічне значення для психологічної науки. Будь-яке психічне явище може бути зрозуміле лише в зв'язку з його матеріальною об'єктивною основою, у взаємодії з іншими явищами $[11$, c. 43$]$.
Згідно досліджень у психології, взаємодія є відносною, матеріальною, супроводжується передачею матеpiï, руху й інформації.

У соціальних науках досліджують взаємодію у соціології, економіці, політології через дослідження соціальних систем.

Шапар (2007) під соціальною взаємодією розуміє процеси впливу різних суб'єктів один на одного, їхній взаємозв'язок, взаємозумовленість, взаємний обмін та ін. та розрізняє п'ять рівнів настанов на взаємодію: домінування, маніпуляція, суперництво, партнерство, співдружність [12, с. 46].

Н.А. Дильдина (2016) стверджує, що соціальна взаємодія реалізується за допомогою взаємного обміну інформацією, емоціями, досвідом, переосмислення власних дій, принципів [13, с. 41].

М.Ю. Максименюк, В.О. Нікітенко (2016) досліджують соціальну взаємодію, що розгортається в суспільстві як складній соціальній системі, породжує мережу соціальних відносин, організовану (гомеостаз) і інтегровану (рівновага) [14, с. 268]. І.Л. Холковська (2016) у своїх дослідженнях вивчає поняття соціальної компетентності як фактору налагодження соціальної взаємодії, від підвищення іiі рівня залежить здатність людини сприймати й обробляти певні обсяги інформації з метою побудови конструктивних соціальних стосунків [15, с. 67].

О.А. Срмакова (2016) систему інститутів, відносин та норм, які формують якісно та кількісно соціальну взаємодію, називає соціальним капіталом. На думку автора, нагромадження соціального капіталу проявляється в зростанні соціальної взаємодії у суспільстві та зумовлено взаємодією двох складових: людського капіталу та інституційного середовища [16, с. 89].

Підхід до розуміння взаємодії у правничих науках базується на базових положеннях функцій та завдань законодавчого регулювання діяльності та існування у громадянському суспільстві різних суб'єктів, їх зв'язків і контактів у різних проявах та рівнях.

Правові взаємодії виникають у результаті співіснування держави та членів суспільства. Внаслідок такої взаємодії відбувається взаємопроникнення держави і громадянського суспільства [17, с. 65].

Взаємодія у економічних системах або економічна взаємодія виникає та існує між тими елементами, які забезпечують процеси відтворення матеріальних благ (виробництва, обміну та споживання) економічного продукту та беруть участь у суспільних виробничих відносинах.

Економічна взаємодія виникає елементами господарського механізму країни, регіону, підприємства, між економічними суб'єктами ринку (іхніми цілями та завданнями діяльності). Економічна взаємодія здійснюється на ринку і між ринками товарів, технологій, капіталу, внаслідок яких відбувається економічний розвиток, виникають і функціонують економічні закони.

У гуманітарних науках вивчають взаємодію у таких сферах, як мова, література, музика, філософія, виконавські види мистецтва, релігія й образотворче мистецтво. Гумані- 
тарні науки досліджують особистість та створені нею продукти. У гуманітарних науках взаємодія досліджується на рівні суб'єктів та налагодження відносин між суб'єктами. Інструментами такого налагодження є діалог, спілкування.

Пріоритет у визначенні поняття взаємодії належить, безумовно, філо-софії, яка визнає ії «філософська категорія, яка відображає особливий тип відношення між об'єктами, за якого кожний з об'єктів діє (впливає) на інші об'єкти, приводячи до їх зміни, і водночас зазнає дії (впливу) з боку кожного з цих об'єктів, що, в свою чергу, зумовлює зміну його стану» $[18$, с. 77].Також стверджується, що взаємодію людина здійснює і використовує як засіб пізнання, знаряддя дії, спосіб організації буття. Як способи взаємодії філософія розглядає спілкування, праця, володарювання, любов, гру.

У технічних науках досліджують закономірності розвитку техніки та ії використання у різних сферах життя суспільства та вивчають системи взаємодії елементів у технічних системах (машини, апарати, прилади, комплекси). Виділяють взаємодію елементів у електротехніці, радіотехніці, біотехнологіях, будівництві тощо. Ю.Т. Савченко (2017) констатує значне розширення об'єктного складу технічних систем, зростання ролі складних та суперскладних технічних систем одночасно із набуттям ними нових властивостей $[19$, с. 50$]$.

Узагальнюючи загальну класифікацію видів взаємодій, доцільно за-уважити, що у сучасному світі вони існують і мають місце їх споріднені фо-рми на перетині кількох ознак. Наприклад, існує соціальноекономічна взаємодія «як процес взаємозв'язаних дій між заінтересованими сторонами, що спрямований на розв'язання протиріч, які виникають при цьому, та сприяє досягненню цілей кожної сторони (збереження і відтворення екосистеми, сталий розвиток підприємства, задоволення потреб споживачів, підвищення якості життя регіональної громади тощо)» [20, с. 290].

Взаємодія у інноваційних процесах належить до об’єктів дослідження соціальних наук, до підвиду економічної взаємодії. Проте чіткого розмежування проводити недоцільно. Адже взаємодія у інноваціях передбачає налагодження відносин між окремими суб'єктами або групами суб'єктів, кожен з яких може бути охарактеризований як відокремлений учасник зі своїми цінностями, менталітетом, потребами, культурою спілкування та здатністю до відкритості, та можливостями працювати у команді інших учасників. Окрім того, реалізація інноваційної діяльності потребуе вивчення зв'язків у системі «людина-техніка», що потребує додаткового дослідження технічних та природничих науках.

«Взаємодія з питань інновацій”, на нашу думку, - це сукупність відносин суб'єктів інноваційної діяльності спільного виконання робіт щодо створення, освоєння, використання та поширення інновацій, спрямованих на підвищення продуктивності реалізації нових ідей інноваційного процесу.

Протікання взаємодії супроводжується зміною стану етапів інноваційного процесу у просторі і часі, через постійне узгодження умов та форм співпраці i частки кожного учасника у ресурсному забезпеченні діяльності та очікуваних економічних результатах від впровадження протягом життєвого циклу інновацій.

Сутність взаємодії проявляється у тому, що суб'єкти погоджено взаємно діють у процесах управління інноваційною діяльністю, індивідуальний результат кожного 3 них впливає на поведінку іншого учасника зокрема та інноваційного процесу загалом. Такі активні відносини змінюють динамічний результат інновацій, утворюють єдине ціле, взаємодіють між собою та із зовнішнім середовищем.

Формування та розвиток систем взаємодії у інноваційних процесах здійснюється у площині механізму інноваційної інфраструктури. Ефектив-ність взаємодії у інноваційних процесах визначається, насамперед, взаємо-відносинами усіх суб'єктів інноваційної системи - науково-дослідних інститутів, університетів, підприємств, органів влади, фінансових установ, консалтингових фірм та ін. Ці відносини забезпечують не тільки вирішення певних питань, а й формують відповідне культурне середовище, без якого неможлива побудова ефективної регіональної інноваційної системи.

Висновки. Дослідження категорії взаємодії та побудова загальної класифікації видів взаємодій дає змогу обгрунтувати різні об'єкти, учасників та способи налагодження відносин у різних сферах наукового пізнання. Побудована класифікація базується на вивченні базових термінів теорії інноватики: системи та зв'язків.

Системи взаємодій у інноваційних процесах віднесено до соціальних видів економічної взаємодії. Проте складність процесів виконання інновацій через присутність людського чиннику та впливу технічних систем вказують та міждисциплінарність цього виду взаємодії.

Подальшого дослідження потребують види систем взаємодії в інноваційних процесах: кластери, мережі, платформи та інше.

\section{Список літератури:}

1. Великий тлумачний словник сучасної української мови / Уклад і голов. ред. В.Т. Бусел. К.; Ірпінь: ВТФ «Перун», 2005. 1728 c.

2. Кваша О.О. Зміст і значення понять «взаємодія» та «система» у філософських і правових досліджень / О.О. Кваша. Держава і право. 2012. Вип. 56. С. 32-38.

3. Тушко К.Ю. До проблеми аналізу соціально-філософських та психологічних основ теорії взаємодії. //Духовність особистості: методологія, теорія і практика. № 5. 2018. С. 205-213.

4. Ортіна Г.В. (2019). Конструктивна взаємодія бізнесу та структур державної влади як основа функціонування реального сектору економіки. Збірник наукових праць Таврійського державного агротехнологічного університету імені Дмитра Моторного (економічні науки). № 1(39). 2019. С. 138-145. 
5. Інноваційна Україна 2020 : національна доповідь / за заг. ред. В.М. Гейця та ін. ; НАН України. К., 2015,336 с.

6. Мина В.В., Коцан-Олинець Ю.Я., Тополевський Р.Б. (2016). Системні зв'язки системи права. Науковий вісник Міжнародного гуманітарного університету. Серія: Юриспруденція. № 20. 2016. С. 8-11.

7. Євтушенко Н.О. Компаративний аналіз поняття консалтингова взаємодія. Економіка. Менеджмент. Бізнес. (1). 2017. С. $42-50$

8. Молчанюк О.В. Гармонійна взаємодія людини та природи як основа виховання в особистості ціннісного ставлення до природи. Духовність особистості: методологія, теорія і практика. 1(88). 2019. С. 98-113.

9. Сурженко В.М., Бессараб А.А. Соціально-екологічні проблеми: сучасні особливості взаємодії суспільства природи. Дніпро: СПД” Охотник”, 2019. Режим доступу: ea.donntu.edu.ua

10. Лопатьєв А.О., Власов А.П., Демічковський А.П. Енергоінформаційні та гравітаційні взаємодії у функціонуванні системи «стрілець-зброя-мішень». Актуальні проблеми фізкультурної освіти. (12). 2017. С. $26-33$.

11. Бродовська В.Й., Грушевський В.О., Патрик І.П. Тлумачний російсько-український словник психологічних термінів: Словник. К.: ВД «Професіонал», 2007. 512 с. С. 43.

12. Шапар В.Б. Ш23 Сучасний тлумачний психологічний словник. Х.: Прапор, 2007. 640 с. С. 46. URL: https://ia802804.us.archive.org/34/items/psyxoloh2007/psyxoloh2007.pdf (дата звернення: 23.05.2020).

13. Дильдина Н.А. (2016). Теоретические аспекты социального взаимодействия. Современные технологии и инновации в педагогической системе образования: сборник научных трудов по материалам I Международной научнопрактической конференции 25 января 2016 г. Нижний Новгород: НОО «Профессиональная наука», 2016.72 с.

14. Максименюк М.Ю., Нікітенко В.О. Формування парадигми інформаційно-комунікативного суспільства як різновиду складної соціальної системи і взаємодії. Гуманітарний вісник Запорізької державної інженерної академії. (66). 2016. C. 266-278.

15. Холковська І.Л. Соціальна компетентність як умова успішної самореалізації особистості. Наукові записки Вінницького державного педагогічного університету імені Михайла Коцюбинського. Серія: Педагогіка і психологія. (47). 2016. C. 63-67.

16. Срмакова О.А. Соціальний капітал як важливий фактор економічного розвитку України та ії регіонів. Вісник Національного університету Львівська політехніка. Проблеми економіки та управління. (847). 2016. С. 88-96.

17. Вінник О., Кравець І. Господарські системи в умовах громадянського суспільства і правової держави: правові аспекти взаємодії. Підприємництво, господарство і право. (11). 2016. С. 62-67.

18. Філософський енциклопедичний словник за ред В.І. Шинкарука. Інститут філософії ім. Г.С. Сковороди НАНУ, Київ: Абрис, 2002. 751 с. 77 с. URL: http://shron1.chtyvo.org.ua/Shynkaruk_Volodymyr/Filosofskyi_entsyklopedychnyi_ slovnyk.pdf (дата звернення: 29.02.2020).

19. Савченко Ю.Т. Технічні системи: сучасний аспект та характерні риси з погляду управління ланцюгами поставок. Науковий вісник Міжнародного гуманітарного університету. Серія: Економіка і менеджмент. 27(2). 2017. C. $47-55$.

20. Тимощук M.Р. Теоретико-прикладні засади соціально-економічної взаємодії підприємств / М.Р. Тимощук, Р.В. Фещур, Н.Р. Яворська. Науковий вісник Ужгородського університету. Серія: Економіка. 2016. Випуск 1(47). С. 285-292.

\section{References:}

1. Velykyi tlumachnyi slovnyk suchasnoi ukrainskoi movy / Uklad i holov. red. V.T. Busel [Large explanatory dictionary of the modern Ukrainian language]. Kuiv, Irpin: VTF «Perun», 2005. 1728 p. (in Ukrainian)

2. Kvasha O.O. Zmist i znachennia poniat «vzaiemodiia» ta «systema» u filosofskykh i pravovykh doslidzhen [The meaning and significance of the concepts of «interaction» and «system» in philosophical and legal]. State and law, 2012, 56, p. 32-38. (in Ukrainian)

3. Tushko K.Yu. Do problemy analizu sotsialno-filosofskykh ta psykholohichnykh osnov teorii vzaiemodii [To the problem of analysis of socio-philosophical and psychological bases of the theory of interaction]. Spirituality of personality: methodology, theory and practice, № 5, 2018, pp. 205-213.

4. Ortyna, A.V. (2019). Konstruktyvna vzajemodija biznesu ta struktur derzhavnoji vlady jak osnova funkcionuvannja realjnogho sektoru ekonomiky [Constructive interaction of business and public authorities as a basis for the functioning of the real sector of the economy]. Collection of scientific works of Tavriya State Agrotechnological University named after Dmitry Motorny (economic sciences), № 1(39), 138-145. (in Ukrainian)

5. Innovatsiina Ukraina 2020 : natsionalna dopovid / za zah. red.V.M. Heitsia ta in. [Innovative Ukraine 2020: national report / for general. red.V.M. Heitz and others]. NAS of Ukraine. K., 2015, 336 p. (in Ukrainian)

6. Myna V.V., Kotsan-Olynets Yu.Ya., Topolevskyi R.B. (2016). Systemni zviazky systemy prava [System connections of the legal system], Scientific Bulletin of the International Humanities University. Series: Jurisprudence, № 20, 2016 , p. 8-11. (in Ukrainian)

7. Jevtushenko N.O. (2017). Komparatyvnyj analiz ponjattja konsaltynghova vzajemodija [Comparative analysis of the concept of consulting interaction. Economy]. Management. Business, (1), 42-50. (in Ukrainian)

8. Molchaniuk O.V. Harmoniina vzaiemodiia liudyny ta pryrody yak osnova vykhovannia $\mathrm{v}$ osobystosti tsinnisnoho stavlennia do pryrody [Harmonious interaction of man and nature as the basis of education in the individual values of nature]. Spirituality of the individual: methodology, theory and practice, 1(88), 2019, p. 98-113. (in Ukrainian) 
9. Surzhenko V.M., Bessarab A.A. Sotsialno-ekolohichni problemy: suchasni osoblyvosti vzaiemodii suspilstva i pryrody [Socio-ecological problems: modern features of interaction between society and nature]. Dnipro: SPD «Hunter», 2019. (in Ukrainian)

10. Lopatiev A.O., Vlasov A.P., Demichkovskyi A.P. (2017). Enerhoinformatsiini ta hravitatsiini vzaiemodii u funktsionuvanni systemy «strilets-zbroia-mishen» [Energy information and gravitational interactions in the functioning of the system «shooter-weapon-target»]. Actual problems of physical education, (12), 2017, p. 26-33. (in Ukrainian)

11. Brodovska V. Y., Hrushevskyi V. O., Patryk I. P. Tlumachnyi rosiisko-ukrainskyi slovnyk psykholohichnykh terminiv: Slovnyk [Explanatory Russian-Ukrainian dictionary of psychological terms: Dictionary]. Kuiv: VD «Professional», 2007. 512 p. P. 43. (in Ukrainian)

12. Shapar V.B. Suchasnyi tlumachnyi psykholohichnyi slovnyk [Modern explanatory psychological dictionary]. Xarkiv: Prapor, 2007, 640 s. Available at: https://ia802804.us.archive.org/34/items/psyxoloh2007/psyxoloh2007.pdf (accessed: 23.05.2020). (in Ukrainian)

13. Dyldyna N.A. Teoretycheskye aspektы sotsyalnoho vzaymodeistvyia [Theoretical aspects of social interaction]. Modern technologies and innovations in the pedagogical system of education: a collection of scientific papers on the materials of the I International scientific-practical conference January 25, 2016. Nizhny Novgorod: NOO «Professional Science», 2016. 72 p. (in Russian)

14. Maksymeniuk M.Yu., Nikitenko V.O. Formuvannia paradyhmy informatsiino-komunikatyvnoho suspilstva yak riznovydu skladnoi sotsialnoi systemy i vzaiemodii [Formation of the paradigm of information and communication society as a kind of complex social system and interaction]. Humanitarian Bulletin of the Zaporizhia State Engineering Academy, (66), 2016, p. 266-278. (in Ukrainian)

15. Kholkovska I.L. Sotsialna kompetentnist yak umova uspishnoi samorealizatsii osobystosti [Social competence as a condition for successful self-realization of the individual]. Scientific notes of Vinnytsia State Pedagogical University named after Mykhailo Kotsyubynsky, Series: Pedagogy and Psychology, (47), 2016, p. 63-67. (in Ukrainian)

16. Yermakova O.A. Sotsialnyi kapital yak vazhlyvyi faktor ekonomichnoho rozvytku Ukrainy ta yii rehioniv [Social capital as an important factor in the economic development of Ukraine and its regions]. Bulletin of the National University of Lviv Polytechnic. Problems of Economics and Management, (847), 2016, p. 88-96. (in Ukrainian)

17. Vinnyk O., Kravets I. Hospodarski systemy v umovakh hromadianskoho suspilstva i pravovoi derzhavy: pravovi aspekty vzaiemodii [Economic systems in the conditions of civil society and the rule of law: legal aspects of interaction], Entrepreneurship, Economy and Law, (11), 2016, p. 62-67. (in Ukrainian)

18. Filosofskyi entsyklopedychnyi slovnyk za red V.I. Shynkaruka [Philosophical encyclopedic dictionary edited by VI Shinkaruk], Institute of Philosophy. G.S. Frying pans of NASU. Kyiv: Abris, 2002. 751 p. Available at: http://shron1.chtyvo.org.ua/Shynkaruk_Volodymyr/Filosofskyi_entsyklopedychnyi_slovnyk.pdf ( : 29.02.2020).

19. Savchenko Yu.T. Tekhnichni systemy: suchasnyi aspekt ta kharakterni rysy z pohliadu upravlinnia lantsiuhamy postavok [Technical systems: modern aspect and characteristics in terms of supply chain management]. Scientific Bulletin of the International Humanities University. Series: Economics and Management, 27(2), 2017, p. 47-55. (in Ukrainian)

20. Tymoshchuk M.R. Feshchur R.V., Yavorska N.R. Teoretyko-prykladni zasady sotsialno-ekonomichnoi vzaiemodii pidpryiemstv [Theoretical and applied principles of socio-economic interaction of enterprises]. Scientific Bulletin of Uzhgorod University. Series: Economics, 2016, issue 1(47), p. 285-292. (in Ukrainian)

\section{ВИДЫ И ФОРМЫ ПРОЯВЛЕНИЯ ВЗАИМОДЕЙСТВИЙ В ИННОВАЦИОННЫХ ПРОЦЕССАХ}

В статье исследована проблема терминологического обоснования системы взаимодействия в инновационных проиессах через определение категорий «система», «связи», «взаимодействие», «экономическое взаимодействие», "взаимодействие в инновационных проиессах». Доказано, что взаимодействие как научная категория является предметом исследований различных отраслей. Дифференциация понимания взаимодействия связана со спецификой отношений, процессов и явлений, которые она описывает, и составом ее участников. Автор сформировала группировки видов взаимодействий по определенным признакам, что позволяет определить место и значение экономических взаимодействий в национальной экономике. Выделена особая роль родственных форм взаимодействий, которые расположены на пересечении нескольких признаков. По результатам поведенных исследований автор дает собственную трактовку понятия «взаимодействие в инновационных процессах» $и$ актуализирует ее современные формы проявления в открытых моделях инновационного процесса.

Ключевые слова: взаимодействие, инновационный процесс, системы взаимодействия, экономическое взаимодействие, взаимодействие в инновационных процессах. 
TYPES AND FORMS OF INTERACTION IN INNOVATION PROCESSES

To implement the tasks of innovative development and implementation of stages of the innovation process, a system of interactions was formed. Many scientists and practitioners in their work come to the conclusion that the concept of innovation is increasingly associated not only with scientific and technical activities or with the stages of development of production, but also with the process of establishing various forms and methods of interaction between workers, organizations and the environment business activities. The topic of the article is devoted to the study of the concept and classification of types of interaction in scientific research. The study is based on the study of the categories «system», "communication», «interaction» as elements of the terminological basis of interaction systems in innovation processes. Was proved that interaction as a scientific category is the subject of research in various fields. Differentiation of understanding of interaction is related to the specifics of relationships, processes and phenomena that it describes, and the composition of its participants. The authors formed a grouping of types of interactions on certain grounds, in particular, described the types of interactions by science, number of contacts, implementation tasks, strength of connections, areas of influence on joint activities, implementation model, number of participants. The developed classification allows to determine the place and importance of economic interactions in the national economy. In the social sciences, interaction in sociology, economics, and political science is studied through the study of social systems. The special role of related forms of interactions, which are located at the intersection of several features, is highlighted. Based on the results of the conducted research, the author presented his own interpretation of the concept of «interaction in innovation processes》 and actualizes its modern forms of manifestation in open models of the innovation process. The essence of interaction is manifested in the fact that the subjects interact in concert in the management of innovation, the individual result of each of them affects the behavior of the other participant in particular and the innovation process in general. Such active relationships change the dynamic result of innovations, form a single whole, interact with each other and with the external environment.

Key words: interaction, innovation process, interaction systems, economic interaction, interaction in innovation processes. 